- $\quad$ AFRICAN JOURNALS ONLINE (AJOL)

Nigerian Journal of Technological Research

1. Vol. 14 No. 3 (2019)/

2. Articles

\title{
Assessment of regulated halo-acetic acids disinfection by-products and their concomitant risks in Ahmadu Bello University Zaria drinking water supply
}

- Shaibu Imodagbe

- Egbenya Musah

- Yahaya Sayyadi Mohammad

- Charles Amen Okuofu

- Akan Bassey Williams

- John Paul Unyimadu

DOI: $10.4314 /$ njtr.v14i3.8

Keywords: Regulated Halo-acetic acids, drinking water, risk of cancer

\begin{abstract}
The conventionally treated drinking water supplied to the Ahmadu Bello University community was assessed for its levels of regulated halo-acetic acids. This is because the Ahmadu Bello University water treatment plant uses calcium hypochlorite in the chlorinated disinfection of its treated water during the treatment process. Longitudinal sampling was undertaken along the treatment and distribution stages of drinking water supply in the community. Between 2008 and 2010, 252 samples were collected and analysed for the regulated halo-acetic acids in accordance with USEPA Method 551.1 (1995) using Methyl Tert-Butyl Ether (MTBE) as extractant and a calibrated Agilent Gas Chromatograph measured their concentrations. All the regulated halo acids recorded their highest concentrations in the chlorinated water sample and these decreased towards house-level water sample except for dichloroacetic acid which increased from the booster station sample with $3.2500 \mathrm{E}-03 \pm 5.8452 \mathrm{E}-03 \mathrm{mg} / \mathrm{L}$ to the house level sample with $3.2511 \mathrm{E}-03 \pm 9.1256 \mathrm{E}-05 \mathrm{mg} / \mathrm{L}$. The total regulated halo-acetic acid (THAAs) concentrations also decreased from the chlorinated sample concentration of $1.8324 \mathrm{E}+00 \pm 8.1252 \mathrm{E}-02 \mathrm{mg} / \mathrm{L}$. to the house level concentration of $4.8826 \mathrm{E}-01 \pm 2.8735 \mathrm{E}-02 \mathrm{mg} / \mathrm{L}$, a situation likely attributable to the
\end{abstract}


turbulent flow during distribution resulting in the increased volatility of the acids in the distribution system. Although not specifically regulated by the Nigerian National Standards, the concentrations of these acids at house level $(4.8826 \mathrm{E}-01 \pm 2.8735 \mathrm{E}-02 \mathrm{mg} / \mathrm{L})$ drinking water is more than the maximum permissible limits of these regulated acids under the USEPA drinking water standard's maximum contaminant level (MCL) of $0.060 \mathrm{mg} / \mathrm{L}$. In view of their implication in increased risk of cancer and other effects including problems of the reproductive system, these acids' concentration in household drinking water need to be rigorously monitored and regulated to minimize their risk to health.

Key words: Regulated Halo-acetic acids, drinking water, risk of cancer

Published

2019-12-17

Issue

Vol. 14 No. 3 (2019)

Section

Articles

Copyright is owned by the Federal University of Technology, Minna, Niger State Nigeria

\section{Journal Identifiers}

eISSN:

print ISSN: 0795-5111

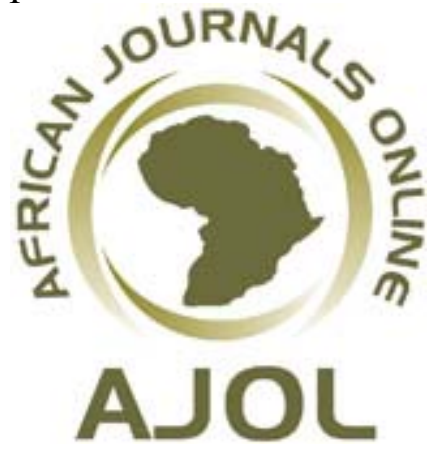

